\begin{tabular}{l} 
RCCS \\
\hline Annual Review
\end{tabular}

RCCS Annual Review

A selection from the Portuguese journal Revista Crítica de Ciências Sociais

$7 \mid 2015$

Issue no. 7

\title{
The Precariat and Class Struggle
}

\section{Guy Standing}

\section{CpenEdition \\ Journals}

\section{Electronic version}

URL: http://journals.openedition.org/rccsar/585

DOI: $10.4000 /$ rccsar.585

ISSN: $1647-3175$

\section{Publisher}

Centro de Estudos Sociais da Universidade de Coimbra

\section{Electronic reference}

Guy Standing, «The Precariat and Class Struggle ", RCCS Annual Review [Online], 7 | 2015, Online since 01 October 2015, connection on 10 December 2020. URL : http://journals.openedition.org/rccsar/585 ; DOI : https://doi.org/10.4000/rccsar.585 


\section{Guy Standing}

School of Oriental and African Studies, University of London, United Kingdom

\section{The Precariat and Class Struggle*}

The world economy is in the midst of a Global Transformation that is producing a new global class structure. A new class is emerging - the precariat - characterised by chronic uncertainty and insecurity. Although the precariat is still a class-in-the-making, divided within itself, its elements are united in rejecting old mainstream political traditions. To become a transformative class, however, the precariat needs to move beyond the primitive rebel stage manifested in 2011 and become enough of a class-for-itself to be a power for change. This will involve a struggle for redistribution of the key assets needed for a good life in a good society in the twenty-first century - not the "means of production", but socio-economic security, control of time, quality space, knowledge (or education), financial knowledge and financial capital.

Keywords: class structure; economic security; precarization of labour; social welfare; world economy.

Every social formation produces its class structure, even if it is superimposed on preceding structures. Today we are in the midst of the Global Transformation, analogous to Karl Polanyi's Great Transformation (Polanyi, 1944). But in this case we are going through the painful construction of a global market system, whereas he was writing about the creation of a national market economy and the institutions for embedding the economy in society.

Whereas in the early $20^{\text {th }}$ century, the proletariat - then the growing core of the working class - was in the vanguard of political and social change, it ceased to have the size or strength or progressive outlook to fulfil that role in the 1980s. It was a force for good for many decades, but it was ultimately stalemated by its intrinsic labourism, wanting as many people as possible in "jobs" and linking social and economic entitlements to the performance of labour.

In the middle decades of the $20^{\text {th }}$ century, capital, the trades unions and labour and social democratic parties all agreed to create a society and a welfare state oriented to labourism, based on a proletarianised majority, oriented to stable labour, with benefits linked to labour. For the proletarian, the main objective was better, 'decent' labour, not escape from labour. The class structure corresponding to that system was relatively easy to describe, with a bourgeoisie - employers, managers and salaried professional employees - confronting a proletariat that between them formed the spine of society.

\footnotetext{
* Article published in Portuguese in RCCS 103 (May 2014). DOI: 10.4000/rccs.5521
} 
Today, a profoundly different global class structure is taking shape. Defined elsewhere (Standing, 2009, 2011), briefly it has seven groups, not all of which are classes in either the Marxian or Weberian senses. Most have distinctive relations of production, relations of distribution, relations to the state, and distinctive modal consciousness.

Below the groups that can be defined in class terms is an underclass, a lumpen-precariat consisting of sad people lingering in the streets, dying miserably. Since they are effectively expelled from society, lack agency and play no active role in the economic system beyond casting fear on those inside it, we may leave them aside, although some elements can be activated in moments of popular protest.

The class groups are not defined by income alone, but they can be listed in descending of average income. At the top of the structure is a plutocracy, a few super-citizens with vast wealth, mostly ill gotten, and with vast informal power, linked in part to financial capital. They are detached from the nation state, often with passports of convenience from several countries. Much of their power is manipulative, through agents, through the funding of politicians and political parties and threats to move their money unless governments comply with their wishes.

Below the plutocracy is an elite, with which it has much in common, although the latter are national citizens somewhere. The two groups act as the effective ruling class, almost hegemonic in their current status. They embody the neoliberal state, and manipulate politicians and the media while relying on financial agencies to maintain the rules in their favour.

Below them is the salariat, those with long-term employment security, high salaries and extensive enterprise or corporate benefits. They serve in state bureaucracies and in the core echelons of corporations. A key to understanding their class position is that they receive a growing proportion of their income and security from capital, in the form of shares. This means that their own incomes could increase if wages are pushed down, if that means the profit share rises and their share payments rise in value. This is one reason for it being misleading to lump the salariat with others below them in one class.

With privatisation of the public sector, and with outsourcing and offshoring of employment by corporations and government agencies, the salariat is shrinking, and many in it fear falling into the precariat, which we will consider shortly. While in most counties the 
salariat will continue to shrink, it will persist, and is something of a 'middle class' ${ }^{1}$ Many in it surely hope to move up into the elite or across into the next group.

That group is what I have called proficians, a growing group who live as contractors, consultants, self-employed "businesses" and the like. They earn high incomes, but live on the edge of burnout and constant exposure to immoral hazards, often breaking laws with abandon. Their numbers are growing, as is their influence on political discourse and popular imagery. It would be foolish to call them part of a single working class, since they are essentially entrepreneurs selling themselves, truly commodified labour power.

Below them in terms of average income is the old proletariat, the core, shrinking fast all over the world. Its remnants will continue, but they no longer have the strength to develop or impose their agenda in the political domain, or even frighten capital in demanding concessions. Welfare states, and regimes of so-called 'labour rights', were built for them, but not for those beneath them in the class structure.

This latter fact has awkward implications for the nature of class struggle and conflict in the coming period. During the $20^{\text {th }}$ century, the proletariat experienced increasingly decommodified labour, through having part of their income derived from the gains from capital in non-wage remuneration.

The most important embodiment of this is the huge pension funds that reward proletarianised workers for long years of "service" through having invested in capital markets to gain funds. As a result, it is very hard to envisage the proletariat being 'revolutionary' or transformative, given how its representatives, most notably labour unions, have entrenched their interests inside capitalism.

\section{The Precariat Defined}

Anyhow, it is below them, in terms of average income, that the precariat is rapidly taking shape. Some commentators have responded to the concept by claiming that precariousness is a social condition. It is that, but a social condition does not act, it does not have human agency. The precariat is a class-in-the-making. We may define it with increasing precision. But as argued shortly, it has a unique characteristic that will make it pivotal to the re-

\footnotetext{
${ }^{1}$ In the sense used by Erik Wright (1978), the salariat has a contradictory class position, but I would argue that it is more clearly on the side of capital today than part of a working class.
} 
embedded phase of the Global Transformation, and the struggles that must occur if that is to be achieved.

The precariat has distinctive relations of production, and these are what most commentators have emphasised in discussing the precariat, although they are not actually the most crucial for understanding it. Essentially, their labour is insecure and unstable, so that it is associated with casualization, informalisation, agency labour, part-time labour, phoney self-employment and the new mass phenomenon of crowd-labour discussed elsewhere (Standing, 2014).

All of these forms of 'flexible' labour are growing around the world. Less noticed is that, in the process, the precariat must perform a growing and high ratio of work-for-labour to labour itself. It is exploited as much off the workplace and outside remunerated hours of labour as in it. That is one factor that distinguishes it from the old proletariat.

Global capital and the state serving its interests want a large precariat, which is why it is a class-in-the-making, not an underclass. Whereas national industrial capital in the Great Transformation wanted to habituate the core part of the proletariat to stable labour and stable living, today's global capital wishes to habituate the precariat to unstable labour and unstable living. This fundamental difference is one reason for believing that to put the proletariat and precariat together as one category would put a block on analytical reasoning and political imagination.

The precariat also has distinctive relations of distribution, in that it relies almost entirely on money wages, usually experiencing fluctuations and never having income security. Again unlike the $20^{\text {th }}$ century proletariat, which experienced labour insecurity that could be covered by social insurance, the precariat is exposed to chronic uncertainty, facing a life of 'unknown unknowns'.

And the precariat has distinctive relations to the state, in having fewer rights than most others. Fundamentally, it has rights insecurity. This is the first time in history when the state is systematically taking away rights from its own citizens, as documented elsewhere (Standing, 2014). More and more people, not just migrants, are being converted into denizens, with a more limited range and depth of civil, cultural, social, political and economic rights. They are increasingly denied what Hannah Arendt called "the right to have rights," the essence of proper citizenship. 
This is a key to understanding the precariat. Its essential character is being a supplicant, a beggar, pushed to rely on discretionary and conditional hand-outs from the state and from privatised agencies and charities operating on its behalf. For understanding the precariat, and the nature of class struggle to come, this is more important than its insecure labour relations.

The final distinctive feature is its class consciousness, which is a powerful sense of status frustration and relative deprivation. This has negative connotations, but it also has a radical transformative aspect, placing it between 'capital' and 'labour'. It is less likely to suffer from false consciousness while performing jobs that come its way, partly because there is no sense of loyalty or commitment in either direction. For the precariat, jobs are instrumental, not life defining. The alienation from labour is taken for granted.

Moreover, this is the first class in history for which the norm is having a higher level of educational qualifications than the labour the person can expect to obtain and be obliged to do. This makes the alienation easier to appreciate. But this imbalance generates deep status frustration, as well as anger about having no sense of a future, no sense that life and society is about advancing to a better state.

But in terms of consciousness, we can see why the precariat is the new dangerous class, because it rejects the old mainstream political traditions, rejecting labourism as much as neoliberalism, social democracy as much as Christian democracy. But it is also dangerous in another sense. A short way of saying this is that it is not currently a class-for-itself, because it is at war with itself in having three forms of relative deprivation, each of which characterises the three varieties of precariat that are currently in tension.

\section{The Three Varieties of Precariat}

The first consists of those dropping out of old working-class communities and families; mostly uneducated, they tend to relate their sense of deprivation and frustration to a lost past, real or imagined. They thus listen to reactionary populist voices of the far right and blame the second and even third variety of precariat for their problems. They might be called the atavists. They tend to respond to charisma. It is this part of the precariat that is being led to the far right (see, e.g., Goodwin and Ford, 2014), due in part to the absence of a progressive agenda that reaches out to it, one that would play on their aspirations rather than on their fear and insecurity. 
The second variety consists of migrants and minorities, who have a strong sense of relative deprivation by virtue of having no present, no home. They might be called the nostalgics. Politically, they tend to be relatively passive or disengaged, except for occasional days of rage when something that appears to be a direct threat to them sparks collective anger. This is what happened in the slums around Stockholm in early 2013 and in Tottenham in London in August 2011, and in other surges of violence.

The third variety consists of the educated, who experience in their irregular labour and in the lack of opportunity to construct a narrative for their lives a sense of relative deprivation and status frustration, because they have no sense of future. One might call them bohemians, but as they are the potentially transformative part of the precariat, the new vanguard, they are open to becoming the progressives.

Peering through the three varieties, one can see that most reject mainstream political agendas of the $20^{\text {th }}$ century. Neoliberalism is anathema. Conservative-Christian democrats are regarded, correctly, as moralistic and generally despised as utilitarian, reaching out to the salariat. And social democrats and labourism are seen as relevant only for the remnants of the proletariat and lower parts of the salariat, having failed the first part of the precariat, being hostile to the second and unpalatable for the third.

Paradoxically but appropriately, in the midst of a crisis due to the failings of the neoliberal project, old-style social democrats have lost their constituency base and are hit by the growth of the precariat more than any other political stream. The social democrats seem to offer a return to the past, without realising that the core of the precariat is alienated from that as well.

Sociologists such as Richard Sennett (1998) picture a loss of a golden age of capitalism and seem to want to recreate what was a male-oriented labourist past, painting current realities as "corroding character," as if that had not been the permanent feature of capitalism. But just as the dangerous class in the late $19^{\text {th }}$ century consisted of those resisting proletarianisation (Jankiewicz, 2012), today's precariat is actually psychologically liberated from labourism and thus the dangerous class. This was beautifully captured by a piece of subversive graffiti daubed by somebody in the indignado movement: "The worst thing would be to return to the old normal."

The key point is that, by various means, there is common ground within the precariat for rejection of the old political consensus and parties of the centre-right and centre-left. This is 
why there is perceived to be a crisis of democracy, because the precariat does not see itself represented and refuses to indulge in the reality of thinning commodified politics. When the indignants of Puerta del Sol scrawl, "I love democracy, but you are absent," their rejection of political parties is profoundly political (Estanque, 2013).

\section{The Precariat as Transformative Class}

However, that last conclusion does not mean that the precariat is apolitical, for there is another sense in which it is the emerging dangerous class. Its immediate task is to go beyond the primitive rebel phase in which it found itself in 2011, of knowing what it is against but not yet enough of a class-for-itself to be a power for change.

Here we must be careful. One achievement of neoliberalism was a degree of linguistic hegemony in capturing the language of political, social and economic discourse, extending into cultural discourse as well. A challenge today is to recapture the language, so as to create an imagined desirable future. This is nothing less than reviving the very idea of the future, which has been lost in the neoliberal dystopia of endless consumerism and electronic breadand-circus plebean existence. The flames of struggle quickly expire in futile days of protest if all the struggle is about is being against what is happening.

This is roughly what has been happening in the mass protests since 2011, which in the main were like a series of fireworks that look and sound spectacular but drift away in coloured smoke. But this phase of collective angst will surely evolve into something more strategic.

As it invents a new language of progress through collective action, the precariat must avoid falling into the well-laid trap of postulating as "revolutionary," an image that is terminally tainted by $20^{\text {th }}$ century history. It must also avoid the sterility of being "reformist," which is what the state would wish it to be, pushing for marginal refinements to the status quo. To become a class-for-itself, the precariat must be transformative.

It must be transformative in realising that the global market economic system requires a new system of distribution, if the trend to greater inequality is to be reversed. It should minimise use of the dated verbiage of $19^{\text {th }}$ century Marxism, without abandoning the emancipatory values that have guided progressives and egalitarians through the ages, and the egalitarian ideas around class struggle. 
A century ago, it made sense to depict the distribution system as largely reflecting capital and labour, profits and wages, with the balance of social forces determining the share of income going to labour, mediated by the state, through taxes, subsidies and benefits, and through a structure of regulations that shaped the relative bargaining strength of the antagonistic class interests.

In the global market economy, there is only one winner in that old model of distribution. In every part of the world, the wage share of national income has dropped sharply, and it is most unlikely to rise. While most attention has been given to the drop in the USA and Europe, labour's share has dropped most in the emerging market giants of China and India.

As the drop in wage share has proceeded, it is the precariat that has borne the worst outcome, while the elite, salariat and shrinking old core have either improved their social income or lost only a little, because they have actually been receiving more of their income from capital, via shares, stock options, extravagant bonuses and rental income. The advanced capitalist countries are increasingly rentier economies.

The message should be clear. The precariat cannot expect real wages to rise. Wages will continue to decline in OECD countries, even if there are occasional rises in some places and for some groups. The labourist answer to the crisis of the Global Transformation is more 'jobs' and higher wages, placing faith in 'Living Wage' campaigns and national minimum wages. But for most in the precariat, wages will cease to provide a dignifying standard of living. The struggle must focus elsewhere.

In an open flexible labour process, the social democratic mantra of more jobs and better wages is like the famous story of the Viking King Canute, who had his throne taken down to the sea, where he sat and told the waves to go back. He apparently did that to show his courtiers the limit of his powers. The more popular version of the story is that telling the waves to go back is simply asking to be drowned. That is where the precariat is today. Jobs promise only insecurity and a need to be ready to seek more loans.

In November 2012, the European Trades Unions called for a 'general strike' across Europe, in what they dubbed a European Day of Action and Solidarity for 'jobs' and against austerity. The organisers must have known it would make no immediate difference to the policies being implemented. Perhaps they hoped the mobilisation would unnerve policymakers and induce them to make changes later. Or was it to show they still had the muscle to bring out the crowd? 
Whatever the aims, it was a call for pity, by and on behalf of supplicants. Give us more subordinated labour as the answer to our suffering! Many who responded with their time must have felt they were dissipating energy in a gesture that was no threat to the forces to which they were opposed. To take to the streets and shout slogans demanding jobs serving hamburgers or loading shelves in supermarkets is hardly dignifying or threatening to the rentier beneficiaries of the global market order. It was a strike of the defeated, not a strike for a forward march to a Good Society.

In thinking of that new forward march, the precariat must struggle for a new system of distribution based on realising that a rising share of total income will continue to flow to financial and global capital, to the plutocracy and elite primarily, with enough to the salariat to cause it split loyalties.

Rich countries, in particular, are becoming rentier economies, receiving more of their income from their activities in the global market. So, the precariat struggle should focus on developing mechanisms to channel income currently going to the plutocracy, elite and salariat to the rest of the population, including the lumpen-precariat but mainly to the precariat, the lowest and most active actual class.

In that struggle to achieve a new system of distribution, the existing global trend towards the creation of national or sovereign wealth funds must be accelerated and must be subject to democratic governance. Today, over 60 countries have national capital funds. Only three operate as mechanisms for progressive distribution - the Alaska Permanent Fund, the Norwegian fund and, surprisingly, the Iranian system. Almost all others serve as vehicles for enriching an already engorged plutocracy and elite. The precariat must struggle to have these transformed into democratic institutions for distribution.

Note the word. The precariat must use words wisely. It should not be tricked into phoney alternatives such as "pre-distribution" - a term concocted on a bad-hair day that has since had brief popularity in British politics, articulated by the leader of the Labour Party, without it meaning anything in particular, except to avoid the difficulty of arguing for redistribution.

The old distribution system does not work on its own terms, that of encouraging investment and labour through effective incentives. There are too many poverty traps (in which going from meagre state benefits to low-wage jobs means a marginal tax rate of over 80\%) and precarity traps (meaning taking low-wage jobs lowers long-term incomes). The precariat can understand all this, whereas the old proletariat would be bemused. It is why 
trades unions have had such difficulty in relating to and appealing to the precariat, and viceversa.

For social democrats, and for other labourists and labour unions, the way forward is to demand higher wages and labour security. But generating more jobs will not be the answer to the distribution question. The precariat has already come to accept that, for some peace of mind as much as anything. Jobs they are likely to obtain are simply instrumental, not life defining, not leading to an old-fashioned career, let alone a life of emancipatory security.

\section{The Redistributive Struggle}

The struggle for redistribution - rather than for a new distribution system - should be reinterpreted, in a way that will put old political parties in intellectual difficulty. What are the crucial assets over which the class struggle should be about? They are not the means of production or 'the commanding heights' of the production system, which shaped the socialist project and class struggle in the $19^{\text {th }}$ and $20^{\text {th }}$ centuries. Talk about taking over the factories or mines would produce embarrassed grins or grimaces in any precariat gathering.

No, the key assets are what are needed for a good life in a good society, one in which more and more people could pursue their own idea of occupation, in which work, real leisure and reproduction could thrive in flexible patterns. Before considering what those assets are, a preliminary point is fundamental to understanding the forthcoming struggle for them.

It is the unique aspect mentioned earlier. The precariat must become a class-for-itself - or enough of it must achieve sufficient commonality - in order to have the strength to abolish itself, through success. This makes it a truly transformative, dangerous class. Other classes in the current neoliberal dystopia are utilitarian, wanting to perpetuate themselves and obtain more from existing structures. They are conservative, or reactionary, in that they are opposed to structural change. Only the precariat is positioned to be truly transformative, building on a struggle for what Hannah Arendt called "the right to have rights."

What are the crucial assets over which the precariat must struggle? As elaborated elsewhere (Standing, 2011, 2014), in brief, they are socio-economic security, control of time, quality space, knowledge (or education), financial knowledge and financial capital. All are unequally distributed, and in terms of control are becoming more so. One can even claim that many of them are more unequally distributed than income itself. 
For instance, whereas the plutocracy, elite, salariat and to some extent proficians have the means of providing themselves with economic security, the precariat is exposed to high risks, as well as a low probability of being able to cope with them or a low probability of being able to recover from them. Above all, it faces chronic uncertainty. The distribution of economic security is more unequal than the distribution of income (ILO, 2004).

At least for the insiders, the old proletariat had labour security, in that social insurance could insure against the risks of unemployment, illness, old age, accidents and so on. It was a manipulative form of security, in that it was provided by the state as long as individual workers conformed to the disciplines and dictates of labour. But the development trajectory was labour-based security, in which contingency risks linked to labour (accidents, illness, unemployment, etc.) were covered, so that compliant workers and their dependent families could look for compensatory entitlements (misleadingly called labour rights) if an adverse event occurred. This was the norm and was expected to become the norm for many others as economic growth advanced. That latter expectation has long ago disappeared.

By contrast, the precariat faces uncertainty, a life of 'unknown unknowns', for which there is no possible insurance system, because actuarially one cannot calculate the probabilities of adverse events occurring. Every aspect of life is uncertain. And when something goes wrong, there is no assured network of support. This is why living on the edge of chronic, unsustainable debt is a norm for the precariat. Obtaining a redistribution of security is fundamental in the coming struggle.

That struggle for security provides a potential source of cross-class alliance, because more and more members of other groups can appreciate the need, and their own likely need, for basic security. Thus policies geared to basic security could appeal to the lower echelons of the middle class, living in increasing fear of falling into the precariat themselves, or fearing their children will do so.

Next, in terms of time as an asset of life, the precariat has no control over his or her time, and its members must be on stand-by, flit between activities, wait for labour, do more work in case they are needed, because they never know what is the optimal way of allocating time. This is why the precariat can be said to suffer from an epidemic of the precariatised mind, unable to focus, undirected towards feasible goals. The precariat needs to have policies to enable it to gain control of its own time. We need a politics of time. 
Next, the struggle for the redistribution of quality space is epitomised in the struggle to revive 'the commons'. This is actually a metaphor, since it conveys more than a fight to preserve public land where people may congregate. It also includes the social and cultural commons, and in a sense the political commons as well.

Deliberative democracy requires public spaces, in which grievances can be articulated and shared, leading to political proposals and the rebirth of collective action, rather than just resistance. In this respect, the precariat needs a flourishing commons, not just to complement its inadequate income but to counter the dominant discourses permeated through a media manipulated by the plutocracy.

Next, a struggle for the redistribution of education is life-defining for the precariat. Here it needs to overcome a sense of false consciousness that education has been spreading and to counter a rhetoric of 'human capital' that has been refined by neoliberals. On the surface, more people are being educated to a higher 'level' than at any time in history. However, real education is very unequally distributed, and more of what is sold as education is fraudulent. While the affluent have access to an education enabling them to liberate the mind and be innovative, the precariat is relegated to a commodified 'human capital' schooling, designed to prepare them for jobs and habituate them to a life of unstable labour, with plebean minds.

The struggle to decommodify education is fundamental if the precariat is to be creative, artistic, subversive and ultimately political and moral. And again, it should find alliances in parts of the salariat and among proficians, the latter being intuitively non-conformists.

The struggle for financial knowledge is about enabling the precariat to be efficient in handling financial matters. The fiscal structure of modern market society is immensely complex, enabling those with access to tax experts to make much more money, while the 'little people' pay more taxes than they should. The right to financial knowledge and to public financial services is more important than many presume. The precariat should soon mobilise around demands for a universal right to receive financial knowledge. In the context of chronic personal indebtedness, due to 'pay-day loan sharks' and student debts that stretch into the future, this is no longer a minor issue.

Above all perhaps, the struggle for an equitable share of financial capital will be crucial, through a basic income and through construction of democratic sovereign wealth funds. But all the struggles that have been mentioned here must be integrated into a transformative 
strategy. Each element opens up possibilities for cross-class alliances with one or more other social groups. After all, a growing proportion of the salariat, proficians and core workers are riven with fear, a fear of failure, a fear of loss. At some point, fear goes from making "cowards of us all," as Hamlet put it, to making lions of outrage.

In many countries, the precariat has been swollen by the austerity era. It is growing in maturity too. In every Great Transformation, there are three phases of struggle. The first is a primitive rebels phase in which the elements of the emerging class search for Recognition, a common identity. To a remarkable degree, this has happened since 2011. Millions more now have a sense of common identity, and know themselves as the precariat, without shame and with a sense of pride. This provides a necessary potential unity for effective collective action. It is not a sufficient condition, but it is a necessary one.

The next phase is a struggle for Representation, having a collective and individual Voice in all agencies of the state, and having the ability to make a noise in the organs of the state, in the media and networks of public discourses. This is coming. The subjectivity of the precariat must be asserted, so that bureaucracies can no longer treat its members as failures to be reformed, made more 'employable' or punished.

The growing awareness of collective Recognition, and the ongoing actions of primitive rebels and mass resistance, must now give way to political re-engagement. This is happening, albeit discordantly, in such entities as the Partido X in Spain, Sygizia in Greece and the M5S in Italy. Ultimately, this should be about the re-politicisation of politics, in the agora, as the precariat demands to turn from being object to being a subject.

To some extent, for example, the upheavals in Geci Park in Istanbul and the uplifting upheavals in Brazilian cities in 2013 can be interpreted as a demand for more inclusionary participatory democracy, in which the precariat should gain effective collective and individual agency.

As gains are made in Recognition and Representation, the struggle for a new distribution system and for a redistribution of access to those key assets will begin to absorb the collective energies of the precariat and those allied to it. Capital funds, basic income for all, occupational communities, new forms of unions or associations, and more beckon. The precariat is taking shape. As Shelley put it in a comparable period of social upheaval two hundred years ago, in the greatest political protest poem ever written in English, inspired by 
the vicious suppression of the emerging working class in a public square, the precariat is reaching the stage when it will realise its power, "Ye are many, they are few!"²

\section{References}

Estanque, Elísio (2013), "Social Movements and Middle-class Rebellion: An Essay on Recent Mass Protests" (mimeo).

Goodwin, Matthew; Ford, Robert (2014), Revolt on the Right: Explaining Public Support for the Radical Right in Britain. London: Routledge.

ILO - International Labour Organization (2004), Economic Security for a Better World. Geneva: International Labour Organization.

Jankiewicz, Stephen (2012), "A Dangerous Class: The Street Sellers of Nineteenth-century London", Journal of Social History, 46(2): 391-415. DOI : 10.1093/jsh/shs096

Olin-Wright, Erik (1978), Class, Crisis and the State. London: New Left Books.

Polanyi, Karl (2001), The Great Transformation: The Political and Economic Origins of Our Time. Boston, MA: Beacon Press [1 $1^{\text {st }}$ ed.: 1944].

Sennett, Richard (1998), The Corrosion of Character: The Personal Consequences of Work in the New Capitalism. New York: Norton.

Standing, Guy (2009), Work after Globalization: Building Occupational Citizenship. Cheltenham: Elgar.

Standing, Guy (2011), The Precariat - The New Dangerous Class. London: Bloomsbury.

Standing, Guy (2014), A Precariat Charter: From Denizens to Citizens. London: Bloomsbury.

2 "The Masque of Anarchy" was written in 1819, following the Peterloo Massacre at St Peter's Field in Manchester, England. 